\title{
Susceptibility of boll weevil to ready-to-use insecticide mixtures
}

\section{Suscetibilidade do bicudo-do-algodoeiro a misturas de inseticidas prontas para uso}

\author{
Eduardo Moreira Barros' (D), Agna Rita dos Santos Rodrigues² (D), Felipe Colares Batista' (D), \\ Anderson Vinnicius de Arruda Machado ${ }^{1}$ (D), Jorge Braz Torres ${ }^{1 *}$ (D)
}

\begin{abstract}
Boll weevil is the major cotton pest in Brazil, and insecticides are widely recommended against it. We determined the susceptibility of boll weevil to insecticides either in single or in mixture ready-to-use formulations, which are registered to spray cotton fields under the hypothesis that mixtures are more toxic to the target pest. Concentration-mortality curves were determined to adult species, simultaneously through dried residues and ingestion. Ten insecticide formulations were studied with five in mixture (lambda-cyhalothrin + thiamethoxam, lambda-cyhalothrin + chlorantraniliprole, thiamethoxam + chlorantraniliprole, and fenitrothion + esfenvalerate) and their five respective single formulations. Cotton leaf discs and cotyledons were dipped into insecticide dilutions prepared by diluting the commercial products into distilled water. Adult mortality was assessed 48 hours after caging adults on treated and untreated materials. The $\mathrm{LC}_{50 \text { s }}$-concentrations varied from 0.004 to $0.114 \mathrm{~g}$ a.i./L, with a relative potency between single and mixture ones, varying from 1.37- to 29.59fold. Furthermore, lambda-cyhalothrin and thiamethoxam in single formulation were the most toxic insecticides to boll weevil. Among insecticide mixtures, only lambda-cyhalothrin + chlorantraniliprole resulted in a synergic effect; whereas the remaining mixtures showed an antagonistic effect. Therefore, except for the mixture of lambda-cyhalothrin + chlorantraniliprole, the remaining mixtures did not enhance toxicity against the boll weevil and should be recommended only when aimed at different purposes.
\end{abstract}

KEYWORDS: Anthonomus grandis grandis; insecticide combination index; chemical control; broad-spectrum insecticide.
RESUMO: Bicudo-do-algodoeiro é a principal praga do algodoeiro no Brasil, sendo o uso de inseticidas amplamente recomendado para o seu controle. A suscetibilidade do bicudo-do-algodoeiro foi determinada a inseticidas em formulação simples ou em misturas prontas para uso, as quais têm sido recomendadas para pulverizar campos de algodão sob a hipótese de serem mais tóxicas à praga alvo. Assim, curvas de concentração-mortalidade foram determinadas para adultos do bicudo contaminados, simultaneamente, via resíduo seco e ingestâo dos inseticidas. Dez formulaçôes foram estudadas, sendo cinco misturas (lambda-cialotrina + tiametoxam, lambda-cialotrina + clorantraniliprole, tiametoxam + clorantraniliprole e fenitrotiona + esfenvalerato) e suas respectivas cinco formulaçóes simples. Folhas e cotilédones do algodoeiro foram mergulhados em diluiçôes do inseticida preparadas com os produtos comerciais e água destilada. A mortalidade adulta foi avaliada 48 horas após o acondicionamento dos adultos em materiais tratados e não tratados. As concentraçóes de $\mathrm{CL}_{50 \text { s }}$ variaram de 0,004 a $0,114 \mathrm{~g}$ i.a./L, com potência relativa entre formulação simples e misturas, variando de 1,37 a 29,59 vezes. A lambda-cialotrina e o tiametoxam em formulaçóes simples foram os inseticidas mais tóxicos para o bicudo. Entre as misturas, aquela preparada com lambda - cialotrina + clorantraniliprole resultou em um efeito sinérgico, enquanto as demais misturas mostraram um efeito antagonista. Portanto, exceto pela mistura de lambda-cialotrina + clorantraniliprole, as demais misturas não demonstraram maior toxicidade para o bicudo-do-algodoeiro e devem ser recomendadas somente quando objetivam finalidades diferentes.

PALAVRAS-CHAVE: Anthonomus grandis grandis; índice de combinação de inseticidas; controle químico; inseticida de largo espectro. 


\section{INTRODUCTION}

The most insecticide use in cotton ecosystem is driven by boll weevil control and it compromises the whole integrated pest management of cotton. The reasons include a series of the pest's life history traits and losses it causes. In Brazil, boll weevil is responsible for the largest number of insecticide sprays against a single target pest species in cotton fields (LIMA JUNIOR et al., 2013; BÉLOT et al., 2016). Cost estimations of cotton pest control indicate boll weevil as the pest that most inflates costs; its presence in cotton fields determines the spray frequency and insecticide choice during spray decision (SHOWLER, 2012; BÉLOT et al., 2016). When boll weevil infestation reaches the economic threshold, at least five sequential sprays are carried out to attain control of adults emerging over $20-25$ days of the developmental period (from oviposition to adult emergence). This practice might be introduced early within crop phenology, due to the susceptibility of the crop to boll weevil attack (budding stage), and be continued during the fruiting period until the boll hardening stage. This decision is imposed by the biology of boll weevil with entire immature stages partially protected inside fruiting structures, with only emerging adults as the target of sprayings. The use of insecticide in cotton makes it the major consumer of insecticides among row crops per hectare cultivated in Brazil (OLIVEIRA et al., 2014), which is also recorded in other cotton regions around the world (OERKE, 2006), and demonstrates a great demand for using the insecticide.

Advancement in integrated pest management of cotton has occurred through genetically modified cotton varieties resistant to lepidopterans (i.e., Bt-cotton), resulting in a reduction in insecticide use (FITT, 2000; NARANJO, 2009; LU et al., 2012), with newer insecticides, which are more specific and less toxic (LAHM et al., 2009; RUDRAMUNI et al., 2011; BARROS et al., 2018) to replace old and non-selective, highly toxic, and broad-spectrum materials. Nonetheless, these advances have generated more benefits in areas where insect pests of cotton are less diverse, compared to the cotton ecosystem in Brazil. The major cotton growing areas in Brazil have a large diversity of sucking pest species not targeted by Bt-cotton, lepidopteran larvae either unsusceptible or with low susceptibility to $\mathrm{Bt}$ toxins, even using pyramided traits (TORRES et al., 2009), and boll weevil, which is the worse cotton pest there can exist (SHOWLER, 2012).

Among the various cotton pest species, the occidental boll weevil form Anthonomus grandis grandis Boheman, 1843 (Coleoptera: Curculionidae) (KUESTER et al., 2012; ALVARADO et al., 2017; JEGER et al., 2017) after infesting a cotton field, curative control is achieved mostly using nonselective broad-spectrum insecticides. New materials offering less impact on non-target organisms, and overall less ecotoxicity should be prioritized in a pest management program (TORRES; BUENO, 2018); however, they usually do not restrain boll weevil population growth like broad-spectrum insecticides do, considering that only the adult stage of the pest is exposed to sprays. The whole development, from eggs to adulthood, takes place partially protected inside cotton fruiting structures (COAKLEY et al., 1969). Besides inflating control costs, by requiring sprayings to reach adults from successive emergences (SHOWLER, 2012; LIMA JUNIOR et al., 2013), recommended broad-spectrum insecticides have a large impact on non-target arthropods, producing either resurgence, or secondary pest species outbreaks, such as mites (WILSON et al., 1998), aphids (GODFREY et al., 2000), and whiteflies (OLIVEIRA et al., 2001).

Regularly 27 active ingredients formulated in 98 commercial products are available in Brazil to spray cotton fields against boll weevil (AGROFIT, 2003). Among these commercial materials, twelve are commercial ready-to-use mixtures. These mixtures are the combination of two active ingredients in a single formulation, hence, avoiding the need to mix different insecticides during application (BRATTSTEN et al., 1986; O'CONNOR-MARER, 2000; CLOYD, 2011) to control different pest species with simultaneous infestations, and using lower field rates (CORBEL et al., 2004). Multiple pest species with different feeding habits commonly infest cotton fields and require broad-spectrum insecticides or mixture of active ingredients. Depending on variety and weather conditions, boll weevil may colonize cotton fields for approximately 60 days, from flower buds to boll hardening ( -40 to 100 days old plants). During this period, cotton crop is also commonly infested by lepidopteran species, whitefly, and stinkbugs. Besides controlling multiple pest species, the insecticide mixture is expected to offer resistance mitigation with multiple target sites (CURTIS, 1985; ATTIQUE et al., 2006; AHMAD et al., 2009; NASIR et al., 2013). Furthermore, it is also expected to increase toxicity against target species (CORBEL et al., 2004). Nonetheless, the outcome of using an insecticide mixture can be additive, synergistic, and antagonistic, depending on active ingredients and pest species targeted (CHOU; TALALAY, 1984). Therefore, the susceptibility of one standard susceptible to boll weevil population was tested using different active ingredients in single, or in mixture formulations to investigate the toxic potency regarding the recommendation of single active ingredient formulation.

\section{MATERIAL AND METHODS}

The study was carried out in the Entomology Unit of the Agronomy Department of Universidade Federal Rural de Pernambuco (UFRPE). Boll weevil adults used in the bioassays originated from field collections at the end of the season, from buds and bolls, exhibited signs of containing an immature weevil inside. The infested material was collected from a commercial cotton field located in Surubim County, 
Pernambuco state $\left(07^{\circ} 53^{\prime} 48.9^{\prime \prime} \mathrm{S}\right.$, and $\left.35^{\circ} 49^{\prime} 19.2^{\prime \prime} \mathrm{W}\right)$, placed in Plexiglas cages $(50 \mathrm{~cm}$ length $\times 40 \mathrm{~cm}$ width $\times 50 \mathrm{~cm}$ height) in the laboratory, and left to wait for adult emergence. Laboratory conditions during the adult rearing and bioassays were set to $25 \pm 1^{\circ} \mathrm{C}$, and a 12:12-hours (L:D) photoperiod. Emerging adults were collected daily from field collected material, and reared in plastic $1 \mathrm{~L}$ pots, fed with cotton buds and young tips of cotton plants prior exposure to the insecticides. Recent studies with other objectives have determined that individuals from this area are susceptible to organophosphate, pyrethroid, and spinosyns (SPÍNDOLA et al., 2013; ROLIM, 2018).

\section{Insecticides}

Insecticides were tested with ready-to-use single or mixture formulations, as presented in Table 1. The commercial formulations Karate Zeon ${ }^{\circledR} 50$ CS (lambda-cyhalothrin $-50 \mathrm{~g} / \mathrm{L}$, Syngenta Proteção de Cultivos Ltda), Actara ${ }^{\circledR} 250$ WG (thiamethoxam - $250 \mathrm{~g} / \mathrm{L}$, Syngenta Proteçáo de Cultivos Ltda), Prêmio ${ }^{\circledR} 200$ SC (chlorantraniliprole - 200 g/L, DuPont Brasil Ltda), Sumithion ${ }^{\circledast} 500 \mathrm{EC}$ (fenitrothion - $500 \mathrm{~g} / \mathrm{L}$, Iharabras S/A Indústrias Químicas) and Sumidan ${ }^{\circledR} 25$ EC (esfenvalerate $-25 \mathrm{~g} / \mathrm{L}$, Iharabras S/A Indústrias Químicas); and the mixtures: Engeo Pleno ${ }^{\circledR} 247$ SC (lambda-cyhalothrin + thiamethoxam - $106+141 \mathrm{~g} / \mathrm{L}$, Syngenta Proteção de Cultivos Ltda), Ampligo ${ }^{\circledast} 150$ SC (lambda-cyhalothrin + chlorantraniliprole $-50+100 \mathrm{~g} / \mathrm{L}$, Syngenta Proteção de Cultivos Ltda), Voliam Flexi ${ }^{\oplus} 300$ SC (thiamethoxam + chlorantraniliprole - $200+100$ g/L, Syngenta Proteçâo de Cultivos Ltda), and Pirephos $^{\circledast} 840$ EC (fenitrothion + esfenvalerate $-800+40$ $\mathrm{g} / \mathrm{L}$, Iharabras S/A Indústrias Químicas) (Table 1), which were ordered from a local specialized market.

\section{Bioassays}

Dose-response curves were determined using dried-residue on treated green material (leaves and buds), allowing tarsal contact and ingestion of treated materials like field spray.
Therefore, bioassay adapted the IRAC method No. 7 of exposure, using vegetal material dipping into insecticide dilutions (IRAC, 2010). Preliminary bioassays for each insecticide and mixture were run using field rates to spray cotton field against boll weevil, $A$. grandis grandis; when they were not recommended for boll weevil control, we used the dosage recommended to cotton bollworm, Chloridea (= Heliothis) virescens (Fabr.) (Lep.: Noctuidae) (AGROFIT, 2003), and always considering the spray volume of $150 \mathrm{~L} / \mathrm{ha}$. We tested a range of concentrations of each tested insecticide to establish LCs approaching 0 and $100 \%$ for adult weevils. From five to seven desired concentrations were prepared using distilled water, containing $0.05 \%$ of the surfactant Will Fix ${ }^{\oplus}$ (Charmon Destyl Chemical Industry Ltda, Campinas City, São Paulo state, Brazil), which alone served as the control treatment. Leaf discs $(8.0 \mathrm{~cm}$ diameter), from young cotton leaves plus cotton buds without bracts, were dipped for 10 seconds into control or insecticide dilutions, and left to air-dry on paper towels for one hour, whereupon they were transferred to glass Petri dishes. 5- 6 days old boll weevil adults were held with their respective leaf discs and flower buds for 48 hours, and then counted as dead if they did not move. To circumvent a thanatosis behavior of adult boll weevils when recording mortality, they were transferred to clean Petri dishes and set over a Hot Plate ${ }^{\circledast}$ (Fisatom mod. 752A, Rio de Janeiro, RJ, Brazil), regulated at $-35^{\circ} \mathrm{C}$; then, only those adults that did not move were counted as dead. Each insecticide concentration was tested with a minimum of 20 adults per concentration, using two replications with the final number from 224 to 320 weevils per insecticide (Table 2).

\section{Data analysis}

Lethal concentrations of each insecticide in single or in mixture and their 95\% fiducial limits (FLs) were estimated with the Probit analysis (FINNEY, 1971), using the Proc Probit of SAS (SAS INSTITUTE, 2001). To calculate the relative potency $\left(\mathrm{RP}_{50}\right)$, insecticides with lower $\mathrm{LC}_{50}$ were considered

Table 1. Active ingredients, commercial products, chemical group, and recommended field rate to spray cotton fields.

\begin{tabular}{|c|c|c|c|}
\hline Active ingredient & Commercial product & Chemical group & Field rate \\
\hline Lambda-cyhalothrin & Karate Zeon 50 CS & Pyrethroid & $300 \mathrm{~mL} / \mathrm{ha}$ \\
\hline Thiamethoxam & Actara 250 WG & Neonicotinoid & $100-200 \mathrm{~g} / \mathrm{ha}^{1}$ \\
\hline Chlorantraniliprole & Premio $200 \mathrm{SC}$ & Diamide & $150 \mathrm{~mL} / \mathrm{ha}^{1}$ \\
\hline Fenitrothion & Sumithion 500 EC & Organophosphate & $1500 \mathrm{~mL} / \mathrm{ha}$ \\
\hline Esfenvalerate & Sumidan $25 \mathrm{EC}$ & Pyrethroid & $1000 \mathrm{~mL} / \mathrm{ha}$ \\
\hline Lambda-cyhalotrhin + Thiamethoxam & Engeo Pleno $247(106+141)$ SC & Pyrethroid + neonicotinoid & $200-250 \mathrm{~mL} / \mathrm{ha}$ \\
\hline Lambda-cyhalothrin + Chloratraniliprole & Ampligo $150(50+100) \mathrm{SC}$ & Pyrethroid + diamide & $300-400 \mathrm{~mL} / \mathrm{ha}$ \\
\hline Thiamethoxam + Chloratraniliprole & Voliam Flexi $300(200+100)$ SC & Neonicotinoid + diamide & $200-250 \mathrm{~mL} / \mathrm{ha}$ \\
\hline Fenitrothion + Esfenvalerate & Pirephos $840(800+40)$ EC & Organophosphate + pyrethroid & $600 \mathrm{~mL} / \mathrm{ha}$ \\
\hline
\end{tabular}

'Field rate recommended to spray cotton fields against Chloridea virescens. 
standard. $\mathrm{RP}_{50 \text { s }}$ and their $95 \%$ FLs were calculated and considered significant when FLs did not include the value 1.0 (ROBERTSON et al., 2007).

To label the outcome effect between single and mixture formulations, the combination index $(\mathrm{CI})$ was determined according to CHOU; TALALAY (1984), using the formula: $\mathrm{CI}=\left\{\left(\mathrm{LC}^{1 \mathrm{~m}} / \mathrm{LC}^{1}\right)+\left(\mathrm{LC}^{2 \mathrm{~m}} / \mathrm{LC}^{2}\right)+\left[\left(\mathrm{LC}^{1 \mathrm{~m}} / \mathrm{LC}^{1}\right)^{*}\left(\mathrm{LC}^{2 \mathrm{~m}} /\right.\right.\right.$ $\left.\left.\left.\mathrm{LC}^{2}\right)\right]\right\}$, where $\mathrm{LC}^{1 \mathrm{~m}}$, and $\mathrm{LC}^{2 \mathrm{~m}}$ stand for the proportion of the lethal concentration $\left(\mathrm{LC}_{50}\right)$ in the mixtures tested; and $\mathrm{LC}^{1}$, and $\mathrm{LC}^{2}$ stand for lethal concentration $\left(\mathrm{LC}_{50 \mathrm{~s}}\right)$, determined when the insecticide is tested in the single formulation. The outcome for CI, CI = 1 stands for additive effect, CI > 1 stands for antagonistic effect; and $\mathrm{CI}<1$ stands for synergistic effect. All values were calculated based on $50 \%$ of mortality.

\section{RESULTS}

Mortality data fit the Probit model ( $p>0.05)$. The estimated $\mathrm{LC}_{50}$ values varied from 0.004 to $0.114 \mathrm{~g}$ a.i./L, resulting in a relative potency (RP) ranging from 1.37- to 29.59-fold (Table 2). The insecticides lambda-cyhalothrin and thiamethoxam, in the single formulation, were the most toxic to boll weevil, compared to other tested insecticides. Boll weevil exposed to the mixture of lambda-cyhalothrin + chlorantraniprole resulted in numerically lower $\mathrm{LC}_{50}$ (ca., $0.005 \mathrm{~g}$ a.i./L), which was statistically similar to lambda-cyhalothrin and thiamethoxam in the single formulation. The insecticides fenitrothion, chlorantraniliprole, and the mixture fenitrothion + esfenvarelate were less toxic to boll weevil with $\mathrm{LC}_{50}$ corresponding to $0.10,0.082$, and $0.114 \mathrm{~g}$ a.i./L, respectively (Table 2). Based on the results, the mixture fenitrothion + esfenvarelate had 29.59-fold lower potency than lambda-cyhalothrin in the single formulation, working as the least toxic formulation to boll weevil adults. Furthermore, fenitrothion and chlorantraniliprole had a relative potency of 26.03- and 21.3-fold, lower than that of lambda-cyhalothrin, used in the single formulation, respectively.

The CI were calculated and set within the outcomes from antagonistic to synergistic for tested insecticide mixtures. Only the mixture of lambda-cyhalothrin + chlorantranliprole resulted in a synergistic effect $(\mathrm{CI}<1)$, whereas the remaining mixtures, lambda-cyhalothrin + thiamethoxam, thiamethoxam + chlorantraniliprole, and fenitrothion + esfenvalerate exhibited antagonistic effect $(\mathrm{CI}>1)$, hence, lacking any additive result $(\mathrm{CI}=1)($ Table 3$)$.

\section{DISCUSSION}

Based on the toxicity of tested materials, the overall outcome indicates that most mixtures are less toxic to boll weevil when compared to their single formulations. This is clearly observed when comparing the mixture of lambda-cyhalothrin and

Table 2. Toxicity of insecticides to Anthonomus grandis grandis through dried residue and ingestion.

\begin{tabular}{|c|c|c|c|c|c|c|c|}
\hline Insecticides & $\begin{array}{l}\text { Percentage in the } \\
\text { formulation (a.i.) }\end{array}$ & $\mathbf{n}$ & DF & Slope ( \pm SE) & $\begin{array}{l}\mathrm{LC}_{50}(95 \% \mathrm{FL}) \\
\text { (g a.i./L) }\end{array}$ & $\begin{array}{l}\text { Relative potency } \\
\qquad(95 \% \mathrm{FL})^{1}\end{array}$ & $\begin{array}{l}\text { chi- } \\
\text { square }\end{array}$ \\
\hline Lambda-cyhalothrin & 100 & 224 & 5 & $1.72 \pm 0.19$ & $\begin{array}{c}0.004 \\
(0.003-0.005)\end{array}$ & - & 0.19 \\
\hline Thiamethoxam & 100 & 224 & 5 & $2.02 \pm 0.25$ & $\begin{array}{c}0.006 \\
(0.004-0.008)\end{array}$ & $\begin{array}{c}1.53 \\
(0.85-2.75)\end{array}$ & 2.86 \\
\hline Chlorantraniliprole & 100 & 256 & 6 & $1.18 \pm 0.14$ & $\begin{array}{c}0.082 \\
(0.058-0.115)\end{array}$ & $\begin{array}{c}21.3 \\
(10.53-43.08)^{*}\end{array}$ & 2.92 \\
\hline Fenitrothion & 100 & 320 & 7 & $2.72 \pm 0.27$ & $\begin{array}{c}0.100 \\
(0.083-0.118)\end{array}$ & $\begin{array}{c}26.03 \\
(16.40-41.3)^{*}\end{array}$ & 11.81 \\
\hline Esfenvalerate & 100 & 256 & 5 & $2.07 \pm 0.56$ & $\begin{array}{c}0.052 \\
(0.033-0.125)\end{array}$ & $\begin{array}{c}13.64 \\
(7.05-26.38)^{*}\end{array}$ & 9.59 \\
\hline $\begin{array}{l}\text { Lambda-cyhalotrhin } \\
\text { + Thiamethoxam }\end{array}$ & $42.9+57.1$ & 224 & 5 & $1.68 \pm 0.19$ & $\begin{array}{c}0.009 \\
(0.008-0.013)\end{array}$ & $\begin{array}{c}2.57 \\
(1.41-4.67)^{*}\end{array}$ & 2.02 \\
\hline $\begin{array}{l}\text { Lambda-cyhalothrin } \\
+ \text { Chloratraniliprole }\end{array}$ & $33.3+66.7$ & 224 & 5 & $1.65 \pm 0.19$ & $\begin{array}{c}0.005 \\
(0.004-0.007)\end{array}$ & $\begin{array}{c}1.37 \\
(0.72-2.63)\end{array}$ & 1.09 \\
\hline $\begin{array}{l}\text { Thiamethoxam + } \\
\text { Chloratraniliprole }\end{array}$ & $66.7+33.3$ & 224 & 5 & $1.58 \pm 0.18$ & $\begin{array}{c}0.010 \\
(0.007-0.014)\end{array}$ & $\begin{array}{c}2.62 \\
(1.31-5.25)^{*}\end{array}$ & 1.55 \\
\hline $\begin{array}{l}\text { Fenitrothion + } \\
\text { Esfenvalerate }\end{array}$ & $96.2+4.8$ & 320 & 7 & $2.92 \pm 0.30$ & $\begin{array}{c}0.114 \\
(0.098-0.131)\end{array}$ & $\begin{array}{c}29.59 \\
(18.76-46.69)^{*}\end{array}$ & 10.59 \\
\hline
\end{tabular}

DF: degree of freedom; FL: fiducial limits; ${ }^{1}$ Relative potency, and respective $95 \%$ fiducial limits; * significant values considering that $95 \%$ of fiducial limits do not include the value 1.0 (ROBERTSON et al., 2007). 
thiamethoxam with a $\mathrm{LC}_{50}$ of $0.009 \mathrm{~g}$ a.i./L, which proportionally corresponds to 0.004 and $0.005 \mathrm{~g}$ a.i. of lambda-cyhalothrin and thiamethoxam, based on the percentage of each insecticide (a.i.) in the mixture, respectively (Table 2). Likewise, in the fenitrothion and esfenvarelate mixtures, $\mathrm{LC}_{50}$ accounts for the same amount of fenitrothion required in either single or mixture formulations (ca. $0.1 \mathrm{~g}$ a.i./L); thus, the same mortality of boll weevil using this mixture would be produced with lambda-cyhalothrin, or fenitrothion in single formulations. What is interesting is that in three out of four tested mixtures, the amounts of active ingredients in the recommended field rates are equal or greater than the amount of the active ingredient in the single formulations (AGROFIT, 2003).

On the other hand, the mixture of chlorantraniliprole and lambda-cyhalothrin caused a reduction of the $\mathrm{LC}_{50}$ by 17 times, compared to chlorantraniliprole in the single formulation, and resulted in a CI lower than 1.0, characterizing a synergistic effect. The $\mathrm{CI}$ has been used to set the toxicity outcome of insecticide mixtures as antagonistic, additive, and synergistic actions (MARTIN et al., 2003; ATTIQUE et al., 2006; WILLMOTT et al., 2013). The synergistic outcome found seems to be related to the reduction in the amount of chlorantraniliprole in the mixture, compared to the single formulation. Despite the reduction in the amount of active ingredients in the mixture, the similar toxicity to boll weevil may be related to the high susceptibility of the tested boll weevil population to lambda-cyhalothrin (SPÍNDOLA et al., 2013; RODRIGUES et al., 2013). Despite the significant reduction in chlorantraniliprole, based on $\mathrm{LC}_{50}$, the toxicity to boll weevil yielded by mixture with thiamethoxam was not as great as that yielded in the mixture with lambda-cyhalothrin. In fact, the $\mathrm{CI}$ indicates an antagonistic outcome. These three insecticides have different modes of action, and it is reasonable that the outcome comes from the action of each active ingredient. Overall explanations for interaction outcomes when using different insecticides were proposed by CORBETT (1974). According to this author, when insecticides exhibit different modes of action and toxicology (i.e., absorption, distribution, biotransformation, and excretion) lack of interaction is expected between them; hence, they act independently. However, it is known that insecticides with different modes of action may also interact in terms of metabolic inhibition; hence, their toxicity can be increased or diminished when they are combined (CLOYD, 2011; CASIDA, 2018).
For instance, the synergistic interaction of organophosphates and pyrethroids would be expected. In our study, however, lack of synergism, when using the mixture of organophospate + pyrethroid (i.e., fenitrothion and esfenvarelate) is likely related to the boll weevil population studied that is still highly susceptible to both pyrethorids and organophosphates (RODRIGUES et al., 2013; ROLIM, 2018). Competition for substrate can also be associated to the strong antagonistic interaction found with lambda-cyhalothrin and thiamethoxam. According to CORBEL et al. (2004), the synergism of pyrethroids and carbamates is due to the greater accumulation of acetylcholine in the synaptic gap, prolonging the time of nervous impulse of pyrethroids and the inhibition of acetylcholinesterase caused by carbamate. Neonicotinoids, on the other hand, act as agonists of acetylcholine, binding to neurotransmitter receptors, which are not degraded by acetylcholinesterase (CASIDA, 2018). Thus, the accumulation of acetylcholine in the synaptic gap caused by exposure to the pyrethroid would result in a competition by the neurotransmitter receptors with the molecules of neonicotinoids reducing their toxic effects.

Considering the difficulties with boll weevil control, mixtures of insecticides have been pursued to spray cotton fields, aiming at enhanced efficacy against boll weevil and multiple target species, and reduced logistic, and cost of pest control. A mixture is a combination of two or more active ingredients in a single formulation (BRATTSTEN et al., 1986; O'CONNOR-MARER, 2000; CLOYD, 2011). Insecticide mixture with distinct modes of action is expected to offer from complementary to synergistic control (NASIR et al., 2013). The expected consequence is a reduction in the amount of insecticide applied when promoting synergism (SUN; JOHNSON, 1960; BYNUM JUNIOR et al., 1997; KHAN et al., 2013), enhanced control of resistant insect populations and delay in resistance selection (AHMAD, 2004; ATTIQUE et al., 2006; AHMAD et al., 2009; NASIR et al., 2013), and control of several pest species with simultaneous occurrence. Therefore, the mixture use is expected to offer broad-spectrum control using fewer toxic compounds with different modes of action.

Nonetheless, based on the toxicity outcome to boll weevil for three out of four tested mixtures, the final amount of active ingredients, considering both insecticides in the mixture, is greater than in single formulations. It is worth mentioning that

Table 3. Index of combination for insecticide mixtures against Anthonomus grandis grandis.

\begin{tabular}{lcccc} 
Insecticide mixtures $(A+B)$ & Proportion & $\mathbf{A}^{1}$ & B $^{1}$ & \\
Lambda-cyhalothrin + Thiamethoxam & $1: 1.33$ & 0.004253 & 0.005657 & 3.11 \\
\hline Lambda-cyhalothrin + Chlorantraniliprole & $1: 2$ & 0.001766 & 0.003534 & 0.52 \\
\hline Thiamethoxam + Chlorantraniliprole & $2: 1$ & 0.006747 & 0.003373 & 1.23 \\
\hline Fenitrothion + Esfenvalerate & $20: 1$ & 0.109714 & 0.005426 & 1.31 \\
\hline
\end{tabular}

'Based on $\mathrm{LC}_{50}$ estimated to the insecticides in single formulations $\mathrm{A}$ and B (g a.i./L); ${ }^{2} \mathrm{ICB}$ calculates after CHOU; TALALAY (1984). 
insecticide interactions in mixture (synergism, additive, and antagonism) can vary, because of the function of each active ingredient in the mixture (CORBEL et al., 2004; KHAN et al., 2013). Therefore, different proportions of the active ingredient in these mixtures and future mixtures addressed against boll weevil should be considered.

New insecticides for cotton pest management have become available, such as chlorantraniliprole, and spinetoram against lepidopterans; pyriproxifen, and cyantraniliprole against whitefly; and pymetrozine against aphids, but they have null or low toxicity against boll weevil. Chlorantraniliprole, for example, exhibited a lower toxicity to boll weevil compared to lambdacyhalothrin and thiamethoxam in single formulations. Release of new insecticides has been limited, because along with the toxicity to the target pest, they must meet toxicological and environmental standards (WARE, 2003). Thus, insecticide mixtures containing insecticide with reduced risk and more specific action is one way to increase their action to help managing the complex of pest, commonly found in cotton ecosystems, and those that are difficult to control, such as boll weevil, bollworms, whiteflies, etc. Furthermore, insecticide mixture may enhance its efficacy with reduced dosage, thus diminishing undesired toxicological effects (CORBEL et al., 2004). According to these authors, the mixture of fenitrothion and esfenvarelate allows a $36 \%$ reduction of the organophospate in the mixture. However, the tested mixture of fenitrothion + esfenvarelate did not promote either additive or synergistic toxicity against boll weevil. In fact, this mixture resulted in an antagonistic outcome compared to the single formulations.

Insecticide mixture may increase the efficacy against one target species, and mitigate insecticide resistance (AHMAD, 2004; ATTIQUE et al., 2006; AHMAD et al., 2009; NASIR et al., 2013). On the other hand, insecticide mixture has limitations, specifically when the outcome becomes antagonistic. Reduction in efficacy can lead to increased dosage and spraying frequency, which increases control costs and resistance selection. Negatively, mixture of insecticides can promote resistance to multiple target sites, reducing the susceptibility of pest species to a different group of insecticides, simultaneously making pest management even harder (AHMAD, 2004). In addition to that, mixing selective insecticides with non-selective ones makes the mixture non-selective to natural enemies (TORRES; BUENO, 2018), for instance, the mixture of chlorantraniprole, considered a new and selective insecticide (BRUGGER et al., 2010; ROUBOS et al., 2014; BARROS et al., 2018) with non-selective insecticide, such as lambda-cyhalothrin (BARROS et al., 2018), and thiamethxoam (TORRES et al., 2003; PRABHAKER et al., 2011). Therefore, in situations in which the action of both insecticides is not required to target different pest species simultaneously, an effective and selective single formulation is recommended to avoid increasing costs and undesired non-target impacts.
Various practices are recommended to restrain boll weevil infestation in cotton fields, which are deployed preventively, including cultural, behavioral, and legislative enforcement methods (TORRES et al., 2015; NEVES et al., 2013; 2018), but after field colonization its population suppression in large scale fields relies mainly on insecticide usage (SHOWLER, 2012; LIMA JUNIOR et al., 2013). Chemical control is the most applied method of cotton pest control in Brazil and in other major cotton growing regions worldwide (WU; GUO, 2005; NARANJO, 2009; WILSON et al., 2018). There are many registered commercial insecticides recommended against cotton pest in Brazil (AGROFIT, 2003). However, the wide use of insecticide results in various drawbacks for pest management, including pest resurgence, secondary pest outbreaks, populations of insects resistant to insecticides, and impacts on non-target organisms, such as natural enemies and pollinators. As summarized by WHALON et al. (2015), pest species of cotton that are common in Brazil, such as two-spotted spider mite, whitefly, cotton bollworms, leafworms, and boll weevil are reported for having resistance to different active ingredients. Thus, the supporting feature for formulating and recommending different active ingredients in ready-to-use mixture is to reduce logistic spraying during tank mixing and to mitigate or at least reduce resistance selection (ATTIQUE et al., 2006; AHMAD et al., 2009; NASIR et al., 2013). In addition to that, the mixture aims to offer growers an option to control multiple species simultaneously, a common situation found in cotton ecosystems, with different species presenting different feeding habits, behaviors, and susceptibility to insecticides. Therefore, the justification for recommending a mixture of tested materials against cotton pests should cover at least one of these goals.

\section{CONCLUSIONS}

The insecticides lambda-cyhalothrin and thiamethoxam are highly toxic against boll weevil in the single formulation, in comparison to the other tested insecticides. Besides that, among the tested mixtures, only those prepared with lambda-cyhalothrin + chlorantraniliprole resulted in a synergistic toxicity to boll weevil. Therefore, the recommendation of ready-to-use insecticide mixture should be judiciously taken when targeting only boll weevil in cotton fields.

\section{ACKNOWLEDGMENTS}

We thank Fundação de Amparo à Ciência e Tecnologia do Estado de Pernambuco (FACEPE) for funding research APQ-01685.01/15, and Conselho Nacional de Desenvolvimento Científico e Tecnológico (CNPq), for research grant Proc. 301739/2016-1. 
AHMAD, M. Potentiation/antagonism of deltamethrin and cypermethrin with organophosphate insecticides in the cotton bollworm, Helicoverpa armigera (Lepidoptera: Noctuidae). Pesticide Biochemistry and Physiology, v.80, n.1, p.31-42, 2004. https://doi.org/10.1016/j. pestbp. 2004.06 .002

AHMAD, M.; SALEEM, M.A.; SAYYED, A.H. Efficacy of different insecticide mixtures against pyrethroid and organophosphateresistant populations of Spodoptera litura (Lepidoptera: Noctuidae). Pest Management Science, v.65, n.3, p.266-274, 2009. https:// doi.org/10.1002/ps.1681

ALVARADO, A.; JONES, R.W.; PEDREZA-LARA, C.; VILLANUEVA, C.O.; PFEILER, E. Reassessment of the phylogeography and intraspecific relationships of western and eastern populations of the boll weevil, Anthonomus grandis Boheman (Coleoptera: Curculionidae), in North America. Biological Journal of Linnean Society, v.122, n.1, p.29-45. 2017. https://doi.org/10.1093/ biolinnean/blx049

ATTIQUE, M.N.R.; KHALIQ, A.; SAYYED, A.H. Could resistance to insecticides in Plutella xylostella (Lep., Plutellidae) be overcome by insecticide mixtures? Journal of Applied Entomology, v.130, n.2, p.122-127, 2006. https://doi. org/10.1111/j.1439-0418.2006.01035.x

BARROS, E.M.; SILVA-TORRES, C.S.A.; TORRES, J.B.; ROLIM, G.G. Short-term toxicity of insecticides residues to key predators and parasitoids for pest management in cotton. Phytoparasitica, v.46, n.6, p.391-404, 2018. https://doi.org/10.1007/ s12600-018-0672-8

BÉLOT, J.L.; BARROS, E.M.; MIRANDA, J.E. Riscos e oportunidades: o bicudo-do-algodoeiro. In: MINISTÉRIO DA AGRICULTURA PECUÁRIA E ABASTECIMENTO (Ed.). Desafios do cerrado. Cuiabá: MAPA, 2016. p.77-118.

BRATTSTEN, L.B.; HOLYOKE, C.W.; LEEPER, J.R.; RAFFA, K.F. Insecticide resistance: challenge to pest management and basic research. Science, v.231, n.4743, p.1255-1260, 1986. https:// doi.org/10.1126/science.231.4743.1255

BRUGGER, K.E.; COLE, P.G.; NEWMAN, IC.; PARKER, N.; SCHOLZ, B.; SUVAGIA, P.; WALKER, G.; HAMMOND, T.G. Selectivity of chlorantraniliprole to parasitoid wasps. Pest Management Science, v.66, n.10, p.1075-1081, 2010. https://doi.org/10.1002/ ps. 1977

BYNUM JUNIOR, E.D., ARCHER, T.L.; PLAPP JR., F.W. Comparison of banks grass mite and twospotted spider mite (Acari: Tetranychidae): responses to insecticides alone and in synergistic combinations. Journal of Economic Entomology, v.90, n.5, p.1125-1130, 1997. https://doi.org/10.1093/ jee/90.5.1125

CASIDA, J.E. Neonicotinoids and other insect nicotinic receptor competitive modulators: progress and prospects. Annual Review Entomology, v.63, p.125-144, 2018. https://doi.org/10.1146/ annurev-ento-020117-043042
CHOU, T.C.; TALALAY, P. Quantitative analysis of dose-effect relationships: the combined effects of multiple drugs or enzyme inhibitors. Advances in Enzyme Regulation, v.22, p.27-55, 1984. https://doi.org/10.1016/0065-2571(84)90007-4

CLOYD, R.A. Pesticide mixtures. In: STOYTCHEYA, M. (Ed.). Pesticides formulations, effects, fate. Rijeka: InTech, 2011 . p.69-80.

COAKLEY, J.M.; MAXWELL, F.G.; JENKINS, J.N. Influence of feeding, oviposition and egg and larval development of the boll weevil on abscission of cotton squares. Journal Economic Entomology, v.62, n.1, p.244-248, 1969. https://doi. org/10.1093/jee/62.1.244

CORBEL, V.; RAYMOND, M.; CHANDRE, F.; DARRIET, F.; HOUGARD, J.M. Efficacy of insecticide mixtures against larvae of Culex quinquefasciatus (Say) (Diptera: Culicidae) resistant to pyrethroids and carbamates. Pest Management Science, v.60, n.4, p.375380, 2004. https://doi.org/10.1002/ps.809

CORBETT, J.R. The biochemical mode of action of pesticides. New York: Academic Press, 1974. 330p.

CURTIS, C.F. Theoretical models of the use of insecticide mixtures for management of resistance. Bulletin of Entomological Research, v.75, n.2, p.259-265, 1985. https://doi.org/10.1017/ S0007485300014346

FINNEY, D.J. Probit analysis. 3. ed. London: Cambridge University Press, 1971.333p.

FITT, G.P. An Australian approach to IPM in cotton: integrating new technologies to minimise insecticide dependence. Crop Protection, v.19, n.8, p.793-800, 2000. https://doi.org/10.1016/ SO261-2194(00)00106-X

GODFREY, L.; ROSENHEIM, J.A.; GOODELL, P.B. Cotton aphid emerges as major pest in SJV cotton. California Agriculture, v.54, n.6, p.26-29, 2000. https://doi.org/10.3733/ca.v054n06p26

INSECTICIDE RESISTANCE ACTION COMMITTEE (IRAC). Susceptibility method test No: 007: Leaf eating Lepidoptera and Coleoptera. 2010. Available from: <http://www.irac-online.org/ wpcontent/ uploads/2009/09/Method007v3june09.pdf $>$. Access on: May 12015.

JEGER, M.; BRAGARD, C.; CAFFIER, D.; CANDRESSE, T.; CHATZIVASSILIOU, E.; DEHNEN-SCHMUTZ. K.; GILIOLI, G.; GREGOIRE, J.C.; ANTON, J.; MIRET, J.; NAVARRO, M.N.; NIERE, B.; PARNELL, S.; POTTING, R.; RAFOSS, T.; ROSSI, V.; UREK, G.; VAN BRUGGEN, A.; VAN DER WERF, W.; WEST, J.; WINTER, S.; GARDI, C.; BERGERETTI, F.; MACLEOD, A. Pest categorisation of Anthonomus grandis. European Food Safety Authority Journal, v.15, n.12, p.50-74. 2017 . https://doi.org/10.2903/j. efsa.2017.5074

KHAN, H.A.A.; AKRAM, W.; SHAD, S.A.; LEE, J. insecticide mixtures could enhance the toxicity of insecticides in a resistant dairy population of Musca domestica L. PlosONE, v.8, n.8, e60929, 2013. https://doi.org/10.1371/journal.pone.0060929 
KUESTER, A.P.; JONES, R.W.; SAPPINGTON, T.W.; KIM, K.S. Population structure and genetic diversity of the boll weevil (Coleoptera: Curculionidae) on Gossypium in North America. Annals of the Entomological Society of America, v. 105, n.6, p.902-916. 2012. https://doi.org/10.1603/AN12072

LAHM, G.P.; CORDOVA, D.; BARRY, J.D. New and selective ryanodine receptor activators for insect control. Bioorganic $\odot$ Medicinal Chemistry Letter, v. 17, n. 12, p.4127-4133, 2009. https://doi.org/10.1016/j.bmc.2009.01.018

LIMA JUNIOR, L.S.; DEGRANDE, P.E.; MIRANDA, J.E.; SANTOS, W.J. Evaluation of the boll weevil Anthonomus grandis Boheman (Coleoptera: Curculionidae) suppression program in the state of Goiás, Brazil. Neotropical Entomology, v.42, n. 1, p.82-88, 2013. https://doi.org/10.1007/s13744-012-0083-3

LU, Y.; WU, K.; JIANG, Y.; GUO, Y.; DESNEUX, N. Widespread adoption of Bt cotton and insecticide decrease promotes biocontrol services. Nature, v.487, n.7407, p.362-365, 2012. https://doi. org/10.1038/nature 11153

MARTIN, T.; OCHOU, O.G.; VAISSAYRE, M.; FOURNIER, D. Organophosphorus insecticides synergise pyrethroids in the resistant strain of cotton bollworm, Helicoverpa armigera (Lepidoptera: Noctuidae) from West Africa. Journal of Economic Entomology, v.92, n.2, p.468-474, 2003. https:// doi.org/10.1603/0022-0493-96.2.468

NARANJO, S.E. Impacts of Bt crops on non-target invertebrates and insecticide use patterns. CAB Review: Perspective of Agriculture and Veterinary Science, Nutrition and Natural Research, v.4, n. 11 , p.1-23, 2009. https://doi.org/10.1079/PAVSNNR20094011

NASIR, M.; IMRAN, M.; AHMAD, M. Pyrethroids synergize new chemical insecticides in field populations of Plutella xylostella (Lepidoptera: Plutellidae). Pakistan Journal of Zoology, v.45, n.3, p.629-633, 2013.

NEVES, R.C.S.; SHOWLER, A.T.; PINTO, E.S.; BASTOS, C.S.; TORRES, J.B. Reducing boll weevil populations by clipping terminal buds and removing abscised fruiting bodies. Entomologia and Experimentalis et Appliata, v.146, n.2, p.276-285, 2013. https:// doi.org/10.1111/eea.12026

NEVES, R.C.S.; TORRES, J.B.; BARROS, E.B.; VIVAN, L.M. Boll weevil within season and off-season activity monitored using a pheromone-and-glue reusable tube trap. Scientia Agricola, v.75, n.4, p.313-320, 2018. http://dx.doi. org/10.1590/1678-992x-2016-0450

O'CONNOR-MARER, P.J. Pesticides. In: O'CONNOR-MARER, P.J. (Ed.). The safe and effective use of pesticides. Oakland: Agriculture \& Natural Resources, 2000. p.65-108.

OERKE, E.C. Crop losses to pests. The Journal of Agricultural Science, v.144, n. 1, p.31-43, 2006. https://doi.org/10.1017/ SOO2 1859605005708

OLIVEIRA, C.M.; AUAD, A.M.; MENDES, S.M.; FRIZZAS, M.R. Crop losses and the economic impact of insect pests on Brazilian agriculture. Crop Protection, v.56, p.50-54, 2014. https://doi. org/10.1016/j.cropro.2013.10.022
OLIVEIRA, M.R.V.; HENNEBERRY, T.J.; ANDERSON, P. History, current status, and collaborative research projects for Bemisia tabaci. Crop Protection, v.20, v.9, p.709-723, 2001. https:// doi.org/10.1016/S0261-2194(01)00108-9

PRABHAKER, N.; CASTLE, S.J.; NARANJO, S.E.; TOSCANO, N.C.; MORSE, J.G. Compatibility of two systemic neonicotinoids, imidacloprid and thiamethoxam, with various natural enemies of agricultural pests. Journal of Economic Entomology, v.104, n.3, p.773-781, 2011. https://doi.org/10.1603/ec10362

ROBERTSON, J.L.; RUSSEL, R.M.; PREISLER, H.K.; SAVIN, N.E. Pesticide resistance. In: ROBERTSON, J.L.; SAVIN, N.E.; RUSSEL, R.M.; PREISLER, H.K. (Eds.). Bioassays with arthropods. Boca Raton: CRC Press, 2007. p.99-114.

RODRIGUES, A.R.S.; SPÍNDOLA, A.F.; TORRES, J.B.; SIQUEIRA, H.A.A.; COLARES, F. Response of different populations of seven lady beetle species to lambda-cyhalothrin with record of resistance. Ecotoxicology and Environmental Safety, v.96, p.53-60, 2013. https://doi.org/10.1016/j. ecoenv.2013.06.014

ROLIM, G.G. Suscetibilidade e resistência do bicudo-do-algodoeiro a inseticidas. 2018. 105p. Tese (Doutorado) - Universidade Federal Rural de Pernambuco, Recife, 2018.

ROUBOS, C.R.; RODRIGUEZ-SAONA, C.; HOLDCRAFT, R.; MASON, K.S.; ISAACS, R. Relative toxicity and residual activity of insecticides used in blueberry pest management: mortality of natural enemies. Journal of Economic Entomology, v.107, n. 1, p.277-285, 2014. https://doi.org/10.1603/EC13191

RUDRAMUNI, T.; REDDY, K.M.S.; KUMAR, C.T.A. Bio-efficacy of new insecticidal molecules against insect-pests of cotton. Journal of Farming Sciences, v. 1, n. 1, p.49-58, 2011.

SAS INSTITUTE. SAS/STAT User's Guide. Version 8.02, TS level 2MO. Cary: SAS Institute, USA. 2001.

SHOWLER, A.T. The conundrum of chemical boll weevil control in subtropical regions. In: PARVEEN, F. (Ed.). Insecticides - Pest Engineering. Croatia: Tech Europe, 2012. p.437-448. https:// doi.org/10.5772/27981

SISTEMA DE AGROTÓXICOS FITOSSANITÁRIOS (AGROFIT). Brasília: Ministério da Agricultura, Pecuária e Abastecimento, 2003. Available from: <http://extranet.agricultura.gov. br/agrofit_cons/principal_agrofit_cons>. Access on: Jun. 062018.

SPÍNDOLA, A.F.; SILVA-TORRES, C.S.A.; RODRIGUES, A.R.S.; TORRES, J.B. Survival and behavioural responses of the predatory ladybird beetle, Eriopis connexa populations susceptible and resistant to a pyrethroid insecticide. Bulletin of Entomological Research, v.103, n.4, p.485-494, 2013.https://doi.org/10.1017/ S0007485313000072

SUN, Y.P.; JOHNSON, E.R. Analysis of joint action of insecticides against house flies. Journal of Economic Entomology, v.53, v.5, p.887-892, 1960. https://doi. org/10.1093/jee/53.5.887 
TORRES, J.B.; BUENO, A.F. Conservation biological control using selective insecticides - a valuable tool for IPM. Biological Control, v.126, p.53-64, 2018. https://doi.org/10.1002/ps.640

TORRES, J.B.; SILVA-TORRES, C.S.A.; BARROS, R. Relative effects of the insecticide thiamethoxam on the predator Podisus nigrispinus and the tobacco whitefly Bemisia tabaci in nectaried and nectariless cotton. Pest Management Science, v.59, n.3, p.315-323, 2003. https://doi.org/10.1002/ps.640

TORRES, J.B.; RUBERSON, J.R.; WHITEHOUSE, M.E.A. Transgenic cotton for sustainable pest management. In: LICHTFOUSE, E. (Ed.). Sustainable agriculture reviews: organic farming, pest control and remediation of soil pollutants. New York: Springer, 2009. p. 45-82.

TORRES, J.B.; VIVAN, L.M.; BASTOS, C.S.; BARROS, E.M. Controle cultural como método de convivência com as pragas do algodoeiro. In: BÉLOT, J.L. (Ed.). O bicudo-do-algodoeiro (Anthonomus grandis Boh., 1843) nos cerrados brasileiros: biologia e medidas de controle. Cuiabá: AMPA, 2015. p 117-142.

WARE, G.W. The pesticide book. 5. ed. Fresno: Thomson Publications, 2003. $418 p$.
WHALON, M.E.; MOTA-SANCHEZ, D.; HOLLINGWORTH, R.M.; DUYNSLAGER, L. Arthropod pesticide resistance database. East Lansing: Michigan State Univversity, 2015. Available from: https://www.pesticideresistance.org/. Access on: Jun. 282015.

WILLMOTT, A.L.; CLOYD, R.A.; ZHU, K.Y. Efficacy of pesticide mixtures against the Western flower thrips (Thysanoptera: Thripidae) under laboratory and greenhouse conditions. Journal of Economic Entomology, v.106, n. 1, p.247-256, 2013. https:// doi.org/10.1603/EC12264

WILSON, L.J.; BAUER, L.R.; LALLY, D.A. Effect of early season insecticide use on predators and outbreaks of spider mites (Acari: Tetranychidae) in cotton. Bulletin of Entomological Research, v.88, n.4, p.477-488, 1998. https://doi.org/10.1017/S000748530004222X

WILSON, L.J.; WHITEHOUSE, M.E.A.; HERRON, G.A. The management of insect pests in Australian cotton: an evolving story. Annual Review of Entomology, v.63, p.215-237, 2018. https://doi. org/10.1146/annurev-ento-020117-043432

WU, K.M; GUO, Y.Y. The evolution of cotton pest management practices in China. Annual Review of Entomology, v.50, p.31-52, 2005. https://doi.org/10.1 146/annurev.ento.50.071803.130349 